DOI: https://doi.org/10.31933/dijdbm.v2i3 Received: 11 Febuary 2021, Revised: 18 March 2021, Publish: 20 April 2021

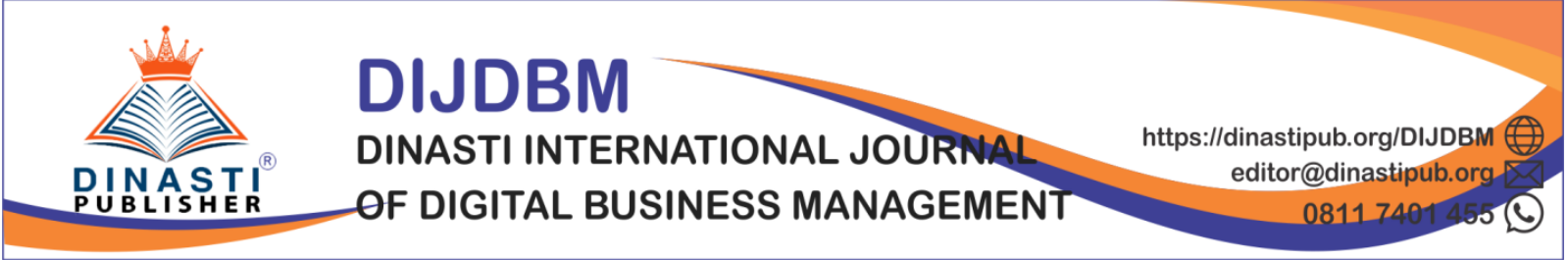

\title{
THE IMPACT OF JOB SATISFACTION, COMMUNICATION AND COMPENSATION TOWARDS EMPLOYEE PERFORMANCE AT PT. PEGADAIAN (PERSERO) IN TANGERANG AREA
}

\author{
Febrinol Febrinol ${ }^{1}$, Anik Herminingsih ${ }^{2}$ \\ ${ }^{1)}$ Universitas Mercu Buana, Jakarta, Indonesia, febrinol.chaniago@gmail.com \\ ${ }^{2)}$ Universitas Mercu Buana, Jakarta, Indonesia, anik_herminingsih@mercubuana.ac.id
}

\section{Corresponding Author: Febrinol}

\begin{abstract}
The research purpose was to revealed and described those impact which is from job satisfaction, communication and compensation towards employee performance at PT. Pegadaian (Persero) in Tangerang Area. The method that used on this research was an explanatory survey to explain and described the phenomena which occured through examining the impact which occured between variables, the research population was 150 people with sample of 109 employees at PT Pegadaian (Persero) in Tangerang Area which consisting of collateral appraisers, cashiers and from micro credit department. Data collection techniques by the surveys through questionnaires, interviews and observations. The analysis method that used was descriptive statistical analysis, validity and reliability test, classic assumption test, which includes normality test, heteroscedasticity test, multicolonierity test and hypothesis test through multiple linear regression analysis techniques which processed by the SPSS 25 program. The results from this research was illustrated that both partially and simultaneously the job satisfaction, communication and compensation have an impact towards employee performance at PT. Pegadaian (Persero) in Tangerang Area.
\end{abstract}

Keywords: Job Satisfaction, Communication, Compensation, Employee Performance.

\section{INTRODUCTION}

The employee performance in a company is very crucial for the company's future development. The Companies need to be able to create conditions which could motivate or encourage employees in developing and improve their abilities and skills optimally. One of the indicators from employee performance which could be seen through the level of discipline of employees at work. As in the company who appointed by the researcher, which is PT Pegadaian (Persero) in Tangerang Area based on employee performance data in 2018 it could be seen that the data on absenteeism and tardiness of employees has an average of $6.7 \%$ and $3.4 \%$. This indicated if the employee performance still not enough optimal and did not met the expectations.

Overall, during period of 2017-2018, approximately $80 \%$ from employees did not performed optimally compared to 2017 and 2018, there seems had a decline in employee 
performance, which indicated by an increase in the percentage of underperforming employees. This clearly illustrates that there were sort of issues in employee performance. On the other words that if all employees' work potentials could reach an maximized, then the overall performance would be much better.

These phenomenon shows that there are some issues in providing good performance at the company. Therefore, the authors were conducted the interviews and observations in form of pre-survey to 20 employees to discovered which variables that has an impact towards the level of employee performance at PT. Pegdaian (Persero) in Tangerang Area. And From all these data, the author find out if the main factors which are suspected to have an impact on the employees performance at PT. Pegadaian (Persero) in Tangerang Area is job satisfaction, employee communication and compensation.

According to the pre-survey which conducted previously, $60 \%$ said there was a problem with job dissatisfaction and $40 \%$ said there was no problem. As for employee communication $70 \%$ stated that communication between employees did not going well and 30\% said there was no problem. Likewise to the compensation, $75 \%$ stated that the compensation earned was irrational and $25 \%$ said there was no problem with that. Furthermore, for performance itself, $60 \%$ stated that there had a decreased in employee performance while $40 \%$ stated that there was nothing happen. Then overall it can be said that There are ongoing issues at PT Pegadaian (Persero) in Tangerang Area regarding job satisfaction, communication between employees, compensation and employee performance. Therefore, the researchers need to conduct research with title of "The Impact of Job Satisfaction, Communication and Compensation towards Employee Performance at PT. Pegadaian (PERSERO)in Tangerang Area".

\section{LITERATURE REVIEW}

\section{Job Satisfaction}

According to Sunyoto (2013:15) job satisfaction is a pleasant or unpleasant feeling state where employees view their work. An employees' attitude towards work related to work situations, cooperation between employees, rewards received from work and those matters relates to physical and psychological factors (Sutrisno, 2011:74). Based on Noe, et al (1997:23) in Fajarto et al (2019) stated that job satisfaction would create pleasant feelings which resulting through the perception that someone job has meets the important value from work itself. According to Luthans (2006:244), there are several factors which affect the job satisfaction such as the job itself, salary, promotion, supervision and colleagues/co-workers.

\section{Communication}

Bernard \& Steiner in Mulyana (2007:68) revealed that the communication is the transmission of information, ideas, emotions, skills and so on through symbols of words, pictures, figures, graphics and etc. The act or process of transmission is what is usually called as communication. The Effective communication would helps to create close bondage between workers and management that will help to strengthen their connection towards organization and helps to achieve an organizational goals (Femi 2014:20). Daft (2010) in Wijaya \& Herminingsih (2015:3-4) said that communication flows based on this 3 (three) directions, namely upward, downward and horizontal communication. Downward communication is a message and information which sent down from top management to subordinates, upward communication is a message which sent from the bottom up such as suggestions and 
improvements and horizontal communication is an exchange of thoughts between fellow workers such as problem solving, coordination and initiative transformed or improvement.

\section{Compensation}

Compensation is an reward or feedback given to employees as an employee performance measurement system (Mahmudi, 2013:75). Based on Rivai \& Sagala (2011:741) compensation is something which employees receives as an contribution of their services to the company and helps the company to achieve its goals. Meanwhile, Wibowo (2016:271) stated that the compensation is the number of packages which organization offered to workers in return for using its labor. Rivai \& Sagala (2011:745) conveyed that several factors which has an impact on compensation namely salary, incentives and indirect compensation.

\section{Employee Performance}

According to Mangkunegara (2016:67) the performance is the result of work both quality and quantity that achieved by person in carrying out the tasks in accordance with the responsibilities which assigned to him. Simamora (2015:327) stated that the employee performance is the level where the employee finally achieved the job requirements. Furthermore, Sedarmayanti (2017:54) in Alfiyah \& Riyanto (2019) revealed that the increasing in employee performance could be view through the increased in organizational which could be measured by predetermined organizational goals. According to Fuad (2004:216) in Sudirno (2017) stated if there are five dimensions which often to use as measurement of individual employee performance, such as quality, quantity, timeliness, effectiveness and work commitment.

\section{Previous Research}

Ghazanfar et. al, (2011), Rahardjo (2016), and Riftiasari (2016) found that job satisfaction had a positive impact towards employee performance. Femi (2014) and Ottieno, et al (2015) found that communication had a positive impact towards employee performance. Ghazanfar, et al (2011), Hameed, et al (2014), Aslam, et al (2015), and Sopiah (2013) found that communication had a positive impact towards employee performance.

\section{Theoretical Framework and Hypothesis}

According to the background above, the research purposed, theoretical studies and prior research which have been mentioned, the framework and hypothesis in this research could be drawn as follows: 


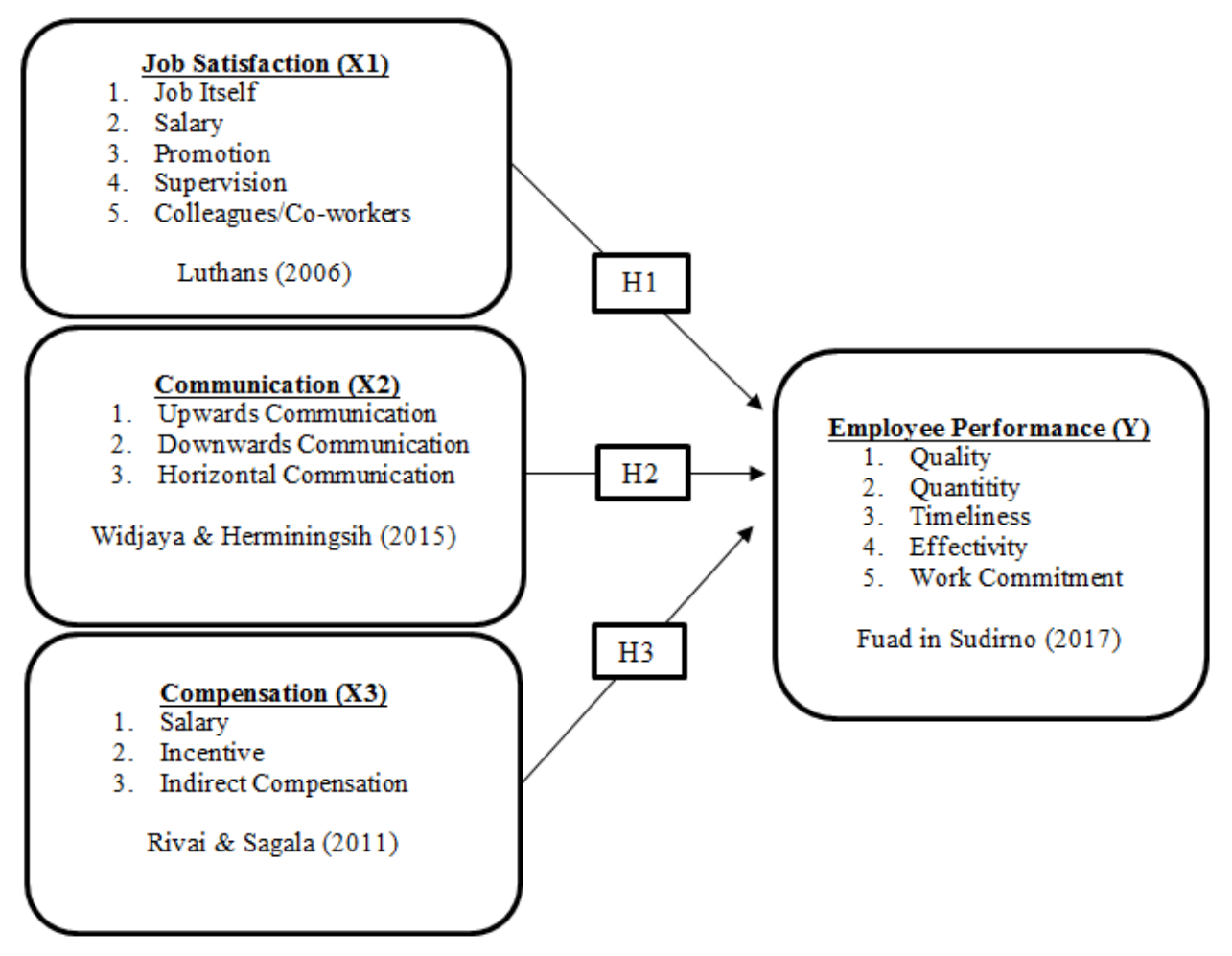

Figure 1. Theoretical Framework

\section{RESEARCH METHODS}

The research design that used here were include in causality research with explanatory survey method to describe and explain the phenomena which occur by analyze the influence between variables. The dependent variable in this research was an employee performance, while the independent variable was job satisfaction, communication and compensation. The population in this research was 150 people who were employees at PT. Pegadaian (Persero) in Tangerang Area. This study used proportionate random sampling method to revealed the research sample. By using slovin rulus at an alpha level of 5\%, the sample in this study amounted to 109 employees consisting of 50 collateral appraisers, 26 cashiers and 33 micro team officers. The data collection method used in this research is a survey method which carried out by distributing questionnaires, interviews and observations. The data analysis method that used in this research was descriptive statistical analysis, validity and reliability test, classic assumption test which includes normality test, heteroscedasticity test, multicolonierity test and hypothesis test through multiple linear regression analysis techniques and processed by the SPSS 25 program.

\section{RESULT AND DISCUSSION}

\section{Descriptive Statistical Analysis}

According to the results from descriptive analysis in this research it was found that the sample's perception of communication was quite high with mean value of 3.892, likewise with the sample's perception of job satisfaction with mean value of 3.879 , but it has low value on compensation of 3.873 and employee performance of 3.876 . 


\section{Validity and Reliability Test}

According to the validity test results, the statement instrument of employee performance shows that the r-count value was between 0.417-0.608, the statement instrument of job satisfaction shows that the r-count was at $0.463-0.621$, the statement instrument of communication shows that the r-count was at 0.466-0.516, and the statement of compensation was indicated that the r-count was at $0.477-0.582$. These results has illusrated that all indicators of the research variables were declared valid, because they have value of r-count was greater than 0.188 .

Table 1. Validity Test Results

\begin{tabular}{lccc}
\hline \multicolumn{1}{c}{ Variable } & Indicator & r-count & Information \\
\hline Employee Performance & EP1-EP7 & $0.417-0.608$ & Valid \\
\hline Job Satisfaction & JS1-JS7 & $0.463-0.621$ & Valid \\
\hline Communication & Comm1-Comm7 & $0.466-0.516$ & Valid \\
\hline Compensation & Comp1-Comp7 & $0.477-0.582$ & Valid \\
\hline
\end{tabular}

Meanwhile, the results from the reliability test on these research variables showed that all variables had a Cronbach's alpha value which greater than 0.6 so they could be declared reliable.

Table 2. Reliability Test Results

\begin{tabular}{lcc}
\hline \multicolumn{1}{c}{ Variable } & Cronbach's Alpha & Information \\
\hline Job Satisfaction & 0.805 & Reliable \\
\hline Communication & 0.757 & Reliable \\
\hline Compensation & 0.725 & Reliable \\
\hline Employee Performance & 0.798 & Reliable \\
\hline
\end{tabular}

\section{Classic Assumption Test}

The results from the normality test shows that the significance value of Asymp. Sig. (2tailed) which is equal to 0.200 , so the data is normally distributed because the probability value was $>0.05$.

Table 3. Normality Test Results

\begin{tabular}{|c|c|c|}
\hline \multicolumn{3}{|c|}{ One-Sample Kolmogorov-Smirnov Test } \\
\hline & & Unstandardized Residual \\
\hline $\mathrm{N}$ & & 109 \\
\hline \multirow[t]{2}{*}{ Normal Parameters ${ }^{\mathrm{a}, \mathrm{b}}$} & Mean & .0000000 \\
\hline & Std Deviation & .26222952 \\
\hline \multirow[t]{3}{*}{ Most Extreme Differences } & Absolute & .051 \\
\hline & Positive & .029 \\
\hline & Negative & -.051 \\
\hline Test Statistic & & .051 \\
\hline Asymp. Sig. (2-tailed) & & $200^{c, d}$ \\
\hline $\begin{array}{l}\text { a. Test distribution is Norm } \\
\text { b. Calculated from data. } \\
\text { c. Lilliefors Significance C }\end{array}$ & & \\
\hline
\end{tabular}

The multicollinearity test results shows that every each independent variable in this research did not have multicollinearity because the tolerance value of each variable is more 
than 0.1 and VIF is less than 10 , so it could be interpreted that the regression model used did not appeared the multicollinearity problems.

Table 4. Multicollinearity Test Results

\begin{tabular}{|c|c|c|c|}
\hline \multicolumn{4}{|c|}{ Coefficients $^{\mathrm{a}}$} \\
\hline \multirow{2}{*}{\multicolumn{2}{|c|}{ Model }} & \multicolumn{2}{|c|}{ Collinearity Statistics } \\
\hline & & Tolerance & VIF \\
\hline \multirow[t]{4}{*}{1} & (Constant) & & \\
\hline & Job Satisfaction & .627 & 1.596 \\
\hline & Communication & .559 & 1.790 \\
\hline & Compensation & .531 & 1.885 \\
\hline
\end{tabular}

a. Dependent Variable: Employee Performance

The results from the heteroscedasticity test shows that there are certain points which spread or around the number 0 , so it can be stated that the data is homogeneous or there are no heteroscedasticity symptoms occured.

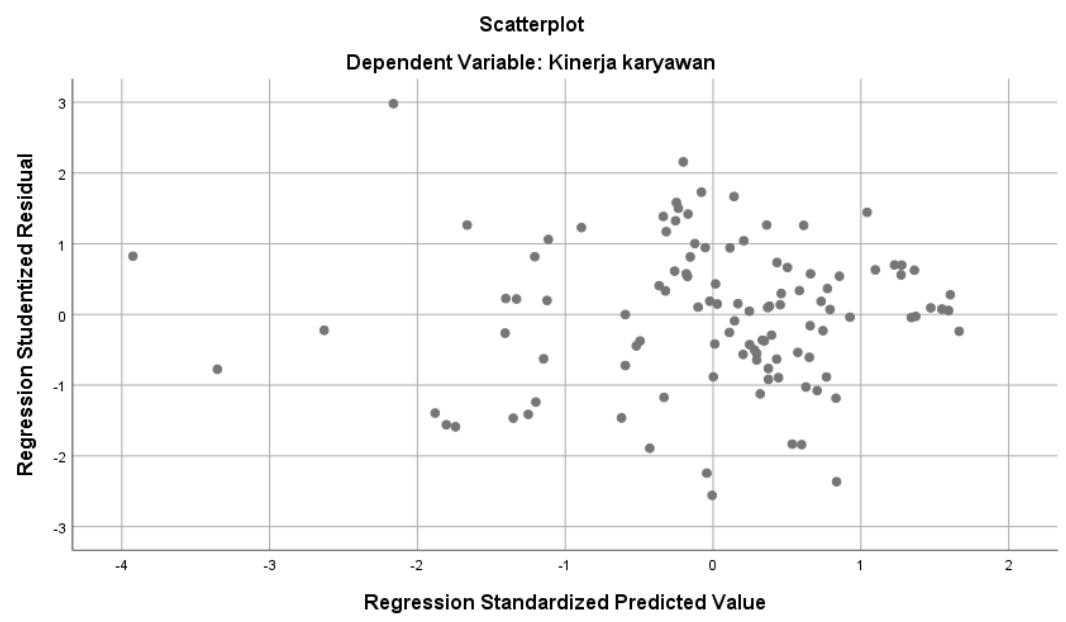

Figure 2. Heteroscedasticity Test

\section{Multiple Linear Regression Analysis}

As stated in the results of multiple linear regression tests with a significance level of 5\%, the regression equation that obtained was: $\mathrm{Y}=0.441+0.145 \mathrm{X} 1+0.290 \mathrm{X} 2+0.449 \mathrm{X} 3+\mathrm{e}$.

1) Job satisfaction variable had a significance value $(0.025<0.05)$ and the t-count was 2.282 . Thus hypothesis test was accepted.

2) Communication variable had a significance value $(0.000<0.05)$ with the $t$-count was 4,460 . Thus hypothesis test was accepted.

3) Compensation variable had a significance value $(0.000<0.05)$ with the t-count was 6.696. Thus hypothesis test was accepted. 
Table 5. Multiple Linear Regression Test Results

\begin{tabular}{|c|c|c|c|c|c|}
\hline \multirow[b]{2}{*}{ Model } & \multicolumn{2}{|c|}{ Unstandardized Coefficients } & \multirow{2}{*}{$\frac{\text { Standardized Coefficients }}{\text { Beta }}$} & \multirow[b]{2}{*}{$\mathrm{t}$} & \multirow[b]{2}{*}{ Sig. } \\
\hline & B & Std. Error & & & \\
\hline 1 (Constant) & .441 & .228 & & 1.939 & .055 \\
\hline Job Satisfaction & .145 & .063 & .154 & 2.282 & .025 \\
\hline Communication & .290 & .065 & .319 & 4.460 & .000 \\
\hline Compensation & .449 & .067 & .491 & 6.696 & .000 \\
\hline
\end{tabular}

According to the $\mathrm{F}$ test results it is known that the F-count value was $81.895>$ F-table 2.648 with significance value of $0.000<0.05$, so it can be interpreted that job satisfaction, communication and compensation simultaneously had an impact towards employee performance. The amount of the simultaneous influence was 69.2\% (Adjusted R-Square = $0.692)$.

Table 6. Simultaneous Significance Test Results (F-Test Statistic)

\begin{tabular}{l|r|r|r|c|c}
\hline \multicolumn{7}{c}{ ANOVA $^{\mathbf{a}}$} & \multicolumn{1}{c}{ F } & Sig. \\
\hline Model & Sum of Squares & \multicolumn{1}{c}{ df } & Mean Square & 51.895 & $.000^{\mathrm{b}}$ \\
\hline 1 & 17.377 & 3 & 5.792 & 81.895 & \\
\hline
\end{tabular}

a. Dependent Variable: Employee Performance

b. Predictors: (Constant), Job Satisfaction, Communication, Compensation

Table 7. The R-Square Determination Coefficient Results

\begin{tabular}{lc|r|r|r|r}
\hline \multicolumn{5}{c}{ Model Summary $^{\mathbf{b}}$} \\
\hline Model & R & R Square & Adjusted R Square & Std. Error of the Estimate & Durbin-Watson \\
\hline 1 & $.837^{\mathrm{a}}$ & .701 & .692 & .26595 & 2.018 \\
\hline
\end{tabular}

a. Predictors: (Constant), Job Satisfaction, Communication, Compensation

b. Dependent Variable: Employee Performance

\section{Inter-Dimensional Correlation Test}

According to the inter-dimensional correlation test results, it was concluded that the strong inter-dimensional correlation could be conveyed as follows:

1) The impact from job satisfaction towards employee performance, through calculation results it was obtained that data with the strongest correlation found in the variable between dimensions of job promotion and work quantity with $r=0.524$.

2) The impact from the employee communication towards employee performance, through calculation results was obtained that the data who has the strongest correlation found in the correlation between the downwards communication dimensions and the quantity of work with $\mathrm{r}=0.533$.

3) The impact from compensation towards the employee performance, those calculation results obtained that the data who has the strongest correlation found in the correlation variables of indirect compensation dimensions and the quantity of work with $r=0.618$. 
Table 8. The Correlation Results Between Dimensions of Each Research Variables

\begin{tabular}{lccccc}
\hline \multicolumn{1}{c}{ Dimension } & $\begin{array}{c}\text { Work } \\
\text { Quality }\end{array}$ & $\begin{array}{c}\text { Work } \\
\text { Quantitiy }\end{array}$ & Timeliness & $\begin{array}{c}\text { Work } \\
\text { Effectivity }\end{array}$ & $\begin{array}{c}\text { Work } \\
\text { Commitment }\end{array}$ \\
\hline Job Itself & 0.331 & 0.409 & 0.300 & 0.365 & 0.291 \\
Sal ary & 0.349 & 0.349 & 0.368 & 0.382 & 0.269 \\
Promotion & 0.292 & 0.524 & 0.421 & 0.491 & 0.456 \\
Supervision & 0.267 & 0.412 & 0.227 & 0.384 & 0.265 \\
Collegues/Co-workers & 0.158 & 0.267 & 0.253 & 0.204 & 0.214 \\
\hline \multicolumn{7}{c}{ Job Satisfaction (X1) } \\
\hline Upwards Communication & 0.361 & 0.533 & 0.366 & 0.471 & 0.484 \\
Downwards Communication & 0.409 & 0.457 & 0.472 & 0.417 & 0.340 \\
Horizontal Communication & 0.433 & 0.494 & 0.449 & 0.449 & 0.384 \\
\hline \multicolumn{7}{c}{ Communication (X2) } \\
\hline Salary & 0.408 & 0.400 & 0.390 & 0.402 & 0.358 \\
Wages & 0.460 & 0.411 & 0.517 & 0.369 & 0.452 \\
Incentive & 0.430 & 0.355 & 0.539 & 0.350 & 0.379 \\
Indirect Compensation & 0.458 & 0.618 & 0.498 & 0.482 & 0.505 \\
\hline \multicolumn{7}{c}{ Compensation (X3) } \\
\hline
\end{tabular}

\section{Discussion}

Drew on the research results, job satisfaction had a significant positive impact towards employee performance at PT Pegadaian (Persero) in Tangerang Area. In other words that the higher the job satisfaction value in a company, the higher the employee performance value would be achieved. The results of this research were in line with the research from Ghazanfar, et al (2011), Rahardjo (2016), and Riftiasari (2016). According to the correlation matrix between the dimensions of the job satisfaction and employee performance, the results of the calculation are that the data with the strongest correlation is in the variable of job promotion and the work quantity. This shows that changes in job satisfaction variables, especially in the dimensions of job promotion, would have the greatest correlation to the work quantity dimension of the employee performance variables. In accordance with the reality which occurs in current research object, it is true that there is a requirement for an employee to be recommended for promotion, seen from the amount of control over the field of work in the sense that an employee is multitalented. Thus it could be explained that job promotion had a sufficient affect on the quantity of work for employees at PT Pegadaian (Persero) in Tangerang Area.

Drew on the research results, it says that the employee communication had a significant positive impact towards employee performance at PT Pegadaian (Persero) in Tangerang Area. In other words that the higher the communication value of employees in a company, the higher employees performance will be earned. These results were in line with research by Femi (2014) and Ottieno, et al (2015). According to the correlation matrix between the dimensions of employee communication variables and employee performance, the results of the calculation said that the data who has the strongest correlation is the correlation between the downwards communication dimensions and the work quantity. This shows that changes in employee communication variables, especially in the way of downwards communication dimension, would have the greatest correlation to the work quantity dimension from the employee performance variable. From the reality on the object of top-down communication research, namely in the form of orders from superiors to subordinates in an effort to increase the quantity of good work to shows an optimal performance improvements as desired by the company. Thus it could be explained that the downwards communication had a sufficient impact towards the quantity of work on employees at PT Pegadaian (Persero) in Tangerang Area. 
Drew on the research results, it says that compensation had a significant positive impact towards employee performance at PT Pegadaian (Persero) in Tangerang Area. In other words that the higher the compensation value in a company, the higher the employees performance will be achived. These results were in line with the research from Ghazanfar, et al (2011), Hameed, et al (2014), Aslam, et al (2015) and Sopiah (2013). According to the correlation matrix between the dimensions of compensation variable and the employees' performance, the results of these calculation tells that the data who has the strongest correlation was in the variable between the indirect compensation dimensions and the work quantity. This shows that changes in the compensation variable, especially the indirect compensation dimension would have the greatest impact to the work quantity dimension of the employee performance variable. In the company where this research was conducted, the indirect compensation in the form of rewards for employees with good performance is very effective in encouraging the employees to maximize the work quantity so the expected performance by the company could be sealed it. Thus it could be explained that job promotion has a strong impact towards the quantity of work on employees at PT Pegadaian (Persero) in Tangerang Area.

\section{CONCLUSION AND SUGGESTION Conclusion}

According to the research findings and discussion, the authors could be draw the following conclusions as follows:

1) Job satisfaction partially had a positive and significant impact towards the Employee Performance at PT Pegadaian (Persero) in Tangerang Area.

2) Employee communication partially had a positive and significant impact towards the Employee Performance at PT Pegadaian (Persero) in Tangerang Area.

3) Compensation partially had a significant positive impact towards the Employee Performance at PT Pegadaian (Persero) in Tangerang Area.

\section{Suggestion}

According to the conclusions above and its discussion that have been mentioned previously, the authors could create some suggestions which could be read as follows:

1) PT Pegadaian (Persero)in Tangerang Area need to further improve regarding the employee satisfaction, especially in the dimensions of job promotion because it has a positive impact towards the employees and It is hoped that one day the management would be more clear towards career paths which provides for the employees who excel the performance,

2) PT Pegadaian (Persero) in Tangerang Area need to further improve in employee communication, particularly in the dimension of downwards communication because it has a positive and significant impact in order to increase the employee performance. As For branch leaders related to branch operations, they need always to carry out the good communication towards the subordinate so then the coordination of the employee team who are subordinates is aligned would be more compatible in an efforts to implementing the targets which have been given by management.

3) PT Pegadaian (Persero) inTangerang Area need to further relate in increasing the compensation, specifically in the indirect compensation dimension because it would have a positive and significant impact in order to improving the employee performance. Indirect compensation in the form of rewards for employees with good performance who are capable to exceed the target above the average standards must be well further improved by the management therefore the employees performance could be increase even more. 
4) The researchers still realizes that if this research is still far from being called as perfect whereas it did not analyzed those matters in more depth probably would find another variables which has a huge impact towards the employee performance and perhaps those indicators within the variables in this research, therefore it is hope in next further research it is expected to improve this research, either by developing other research variables and research indicators and that would be great. There are other variables which could be used as a reference for future researchers such as: work motivation, leadership style, work competence, organizational culture, reward systems and other factors that influence the employee performance.

\section{REFERENCES}

Alfiyah, N., \& Riyanto, S. (2019). The Effect of Compensation, Work Environment and Training on Employees' Performance of Politeknik LP3I Jakarta. International Journal of Innovative Science and Research Technology, 4(5), 947-955.

Aslam, et al. (2015). Impact of Compensation and Rewards System on The Performance of An Organization: An Empirical Study on Banking Sector of Pakistan. European Journal of Business and Social Sciences, 4(08).

Fajarto, S.P, Aima, M.H., \& Karsono, B. (2019). The Effect of Compensation and Job Satisfaction on Increasing Productivity of Asuransi Jasindo Head Office Employees Mediated by Motivation Variable. International Journal of Innovative Science and Research Technology, 4(7), 100-113.

Femi. (2014). The Impact of Communication on Workers' Performancce in Selected Organizations in Lagos State, Nigeria. IOSR Journal of Humanities and Social Science, 9(8), Ver. II, 75-82.

Ghazanfar, et al. (2011). A Study of Relationship between Santisfaction, compensation with performance and work motivation. Jurnal Managementi India. Journal of Management, 24(6), 123-146.

Hameed, et al. 2014. Impact of Compensation on Employee Performance (Empirical Evidence from Banking Sector of Pakistan. International Journal of Business and Social Science, 5(2).

Luthans, F. (2006). Perilaku Organisasi. Edisi Sepuluh. Terjemahan. Yogyakarta: Andi Offset.

Mahmudi. (2013). Manajemen Kinerja Sektor Publik. Sekolah Tinggi Ilmu Manajemen YKPN : Yogyakarta.

Mangkunegara, A. A. A. P. (2016). Manajemen Sumber Daya Manusia Perusahaan. Remaja Rosdakarya. Jakarta.

Mulyana, D. 2017. Ilmu Komunikasi: Sebagai Pengantar. Bandung: PT Remaja Rosda Karya.

Ottieno, et al. (2015). Effect of Employee Communication on Organization Performance in Kenya's Holticutura Sector. International Journal of Business Administration, 6(2).

Raharjo, K.A. (2016). Pengaruh Motivasi, Kepuasan Kerja dan Komitmen Organisasi terhadap Kinerja Karyawan pada PT Sumber Urip Sejati di Surabaya. Journal of Managemen, 19(3), 361-383.

Riftiasari, D. (2016). Pengaruh Motivasi dan Kepuasan Kerja terhadap Kinerja Karyawan pada Perusahaan Baja. Jurnal Manajemen Indonesia. Journal of Management, 2(3), 217230.

Rivai \& Sagala. (2011). Manajemen Sumber Daya Manusia untuk Perusahaan. Rajawali Pers. Jakarta.

Simamora, H. (2015). Manajemen Sumber Daya Manusia. Yogyakarta: STIEY. 
Sopiah. (2013). The Effect of Compensation towards Job Satisfaction and Job Performance of Outsourcing Employees of Syariah Banks in Malang Indonesia. International Journal of Learning \& Development, 3(2).

Sudirno, D. (2017). Gaya Kepemimpinan Partisipatif dan Budaya Organisasi Birokratis dalam meningkatkan kinerja pegawai pada Badan Pengelolaan Lingkungan Hidup (BPLH) Kabupaten Majalengka. Jurnal Ilmiah Manajemen \& Akuntansi, 4(1).

Sunyoto, D. (2013). Teori, Kuesioner, dan Proses Analisis Data Perilaku Terhadap Kinerja Individual. Universitas Katolik Widya Mandala Madiun.

Sutrisno, E. (2011). Manajemen Sumbr Daya Manusia, Kencana. Jakarta.

Wijaya, D.K. \& Herminingsih, A. (2015). Pentingnya Komunikasi Organisasi, Motivasi Kera dan Kompensasi untuk Meningkatkan Kinerja Guru. JEAM, 14, 1-16.

Wibowo. (2016). Manajemen Kinerja. Rajawali Pers. Jakarta. 